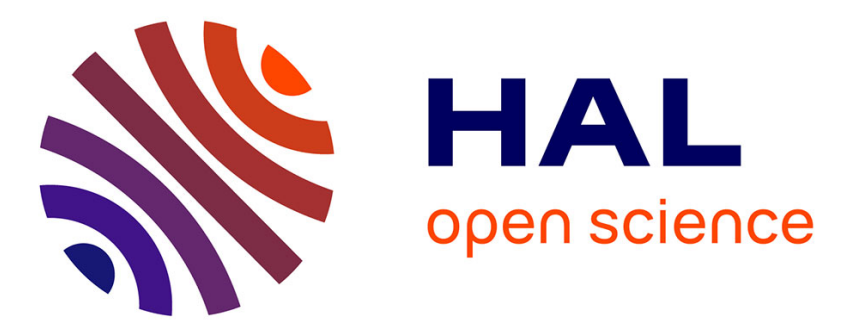

\title{
The influence of overweight and insulin resistance on breast cancer risk and tumour stage at diagnosis: a prospective study
}

Anne E. Cust, Tanja Stocks, Annekatrin Lukanova, Eva Lundin, Göran Hallmans, Rudolf Kaaks, Håkan Jonsson, Pär Stattin

\section{To cite this version:}

Anne E. Cust, Tanja Stocks, Annekatrin Lukanova, Eva Lundin, Göran Hallmans, et al.. The influence of overweight and insulin resistance on breast cancer risk and tumour stage at diagnosis: a prospective study. Breast Cancer Research and Treatment, 2008, 113 (3), pp.567-576. 10.1007/s10549-008-99588. hal-00478323

\section{HAL Id: hal-00478323 \\ https://hal.science/hal-00478323}

Submitted on 30 Apr 2010

HAL is a multi-disciplinary open access archive for the deposit and dissemination of scientific research documents, whether they are published or not. The documents may come from teaching and research institutions in France or abroad, or from public or private research centers.
L'archive ouverte pluridisciplinaire HAL, est destinée au dépôt et à la diffusion de documents scientifiques de niveau recherche, publiés ou non, émanant des établissements d'enseignement et de recherche français ou étrangers, des laboratoires publics ou privés. 


\title{
The influence of overweight and insulin resistance on breast cancer risk and tumour stage at diagnosis: a prospective study
}

\author{
Anne E. Cust - Tanja Stocks - Annekatrin Lukanova - Eva Lundin • \\ Göran Hallmans · Rudolf Kaaks · Håkan Jonsson · Pär Stattin
}

Received: 25 January 2008/ Accepted: 26 February 2008/Published online: 11 March 2008

(C) Springer Science+Business Media, LLC. 2008

\begin{abstract}
It is hypothesized that insulin resistance and related metabolic factors may influence breast cancer risk, however the epidemiological evidence remains inconclusive. We conducted a case-control study nested in a prospective cohort in Northern Sweden, to clarify the associations of body mass index (BMI), leptin, adiponectin,
\end{abstract}

Anne E. Cust and Tanja Stocks contributed equally to this work.

\section{A. E. Cust}

Centre for MEGA Epidemiology, The University of Melbourne, Melbourne, Australia

\section{A. E. Cust}

School of Public Health, The University of Sydney,

Sydney, Australia

\section{A. E. Cust}

Nutrition and Hormones Unit, International Agency for Research on Cancer, Lyon, France

\section{T. Stocks $(\bowtie) \cdot$ P. Stattin}

Department of Surgical and Perioperative Sciences, Urology and Andrology, Umeå University, 90185 Umeå, Sweden

e-mail: tanja.stocks@urologi.umu.se

\section{A. Lukanova $\cdot$ R. Kaaks}

Division of Cancer Epidemiology, German Cancer Research

Center, Heidelberg, Germany

E. Lundin

Department of Medical Biosciences, Pathology,

Umeå University, Umeå, Sweden

\section{G. Hallmans}

Department of Public Health and Clinical Medicine,

Nutritional Research, Umeå University, Umeå, Sweden

\section{H. Jonsson}

Department of Radiation Sciences, Oncology,

Umeå University, Umeå, Sweden
C-peptide, and glycated haemoglobin (HbAlc) with breast cancer risk. We also investigated whether these associations may be modified by age at diagnosis, tumour stage, and oestrogen and progesterone receptor status. During follow-up, 561 women developed invasive breast cancer and 561 matched controls were selected. Conditional logistic regression was used to calculate odds ratios (OR) as estimates of relative risk, and $95 \%$ confidence intervals (CI). The associations of BMI, leptin and HbA1c with breast cancer risk differed significantly according to whether the tumour was diagnosed as stage I or stage II-IV $\left(P_{\text {heterogeneity }}\right.$ all $\left.<0.05\right)$. These factors were significantly inversely associated with risk in the group of stage I tumours, with ORs for top vs. bottom tertile for BMI of $0.48\left(95 \%\right.$ CI, $\left.0.30-0.78, P_{\text {trend }}=0.004\right)$; leptin, 0.64 (95\% CI, 0.41-1.00, $\left.P_{\text {trend }}=0.06\right)$; and HbAlc, 0.47 (95\% CI, 0.28-0.80, $P_{\text {trend }}=0.005$ ). For stage II-IV tumours, there was a suggestion of an increased risk with higher levels of these factors. There were no significant differences in the associations of BMI, leptin, adiponectin, C-peptide and HbA1c with breast cancer risk in subgroups of age at diagnosis or tumour receptor status. This prospective study suggests that BMI, leptin and HbA1c influence breast tumour initiation and progression.

Keywords Adiponectin - Breast cancer - C-peptide . Glycated haemoglobin · Leptin · Obesity · Overweight

\section{Introduction}

The association of obesity with breast cancer is a complex one: a number of studies have shown a direct association after menopause, but obesity appears to confer a slight protection during fertile life [1]. Further, the strength of the 
association may differ by the oestrogen and progesterone receptor (ER/PR) status of the tumours [2,3] and may be particularly relevant to advanced disease and cancer progression [4]. The exact mechanisms responsible for the complexity of the effect of obesity on breast cancer risk remain unknown. Obesity has effects on a number of hormones and growth factors potentially linked to breast cancer. A major cluster of obesity-related metabolic consequences include altered concentrations of circulating adipocytokines, and development of insulin resistance including hyperinsulinaemia and impaired glucose metabolism [5]. Studies examining these factors could have a substantial public health impact as many of these factors are modifiable. In addition, estimating these associations in different population or tumour subgroups may clarify the aetiological role of these factors and identify susceptible periods of tumour development. However, so far, relatively few prospective epidemiological studies have examined how these different metabolic components may be related to breast cancer risk and tumour progression, and the results have been largely inconclusive.

The aim of this prospective study, nested within The Northern Sweden Health and Disease Cohort, was to clarify the associations of factors related to overweight and insulin resistance, including body mass index (BMI), leptin, adiponectin, C-peptide and glycated haemoglobin (HbAlc) with breast cancer risk. We also investigated whether these associations may be modified by age at diagnosis, ER/PR status of the tumour, and tumour stage.

\section{Material and methods}

The study cohort

The Northern Sweden Health and Disease Cohort consists of three subcohorts; the Västerbotten Intervention Project (VIP), the Northern Sweden WHO Monitoring of Trends of Cardiovascular disease study (MONICA) and the Mammography Screening Project (MSP). The present study was based on participants in the VIP and the MSP.

The VIP is an ongoing project since 1985, to which all residents of Västerbotten county are invited to a health survey at the age of 40, 50 and 60 years; between 1985-1996, residents were also invited at the age of 30 . About $59 \%$ of invited persons take part in the health survey and participants have been shown to have similar socioeconomic status as the background population [6]. Instructions before the health survey are to fast for a minimum of $8 \mathrm{~h}(4 \mathrm{~h}$ before 1992) and to avoid physical activity, smoking and snuffing during the last hours prior to the survey. In the present study, $95 \%$ of subjects from the VIP had fasted for $4 \mathrm{~h}$ or more before the health examination. The survey includes measurements of height and weight, and a blood draw. The health survey also includes a questionnaire, including questions on social life, lifestyle and medication.

The MSP has been ongoing since 1995. All women residing in Västerbotten county and who are 50-69 years old are invited every second year for breast cancer screening with mammography. Participants of the MSP are asked to donate blood for future research. Fasting before the examination is not required but fasting time since last meal is recorded; $95 \%$ of subjects from the MSP in the current study had fasted for less than $4 \mathrm{~h}$. The screening examination includes a questionnaire on height, weight, menstruation, reproductive history, a brief question on family history of cancer if known, and on medication use. Since September 1998, height and weight is measured in the MSP. For subjects from the MSP, we used the best data available for height and weight; (1) from measurements at baseline (83 subjects), (2) from questionnaires (561 subjects) and (3) from the closest date ( $\leq 8$ years) with measured or selfreported data from another examination in the MSP or the VIP (37 subjects). Information on hormone replacement therapy (HRT) use was obtained from an open question in the questionnaire on medication use, and number of births and age at first delivery were obtained through a linkage with the birth registry, and, in the MSP cohort, also through questionnaires.

For participants of the VIP and the MSP who have given permission for use of their blood samples in research, blood samples are fractioned into plasma, buffy coat and erythrocyte aliquots and cryopreserved at $-80^{\circ} \mathrm{C}$. In September 2005, blood had been collected from 36,711 participants in the VIP and from 27,787 participants in the MSP. If a subject had participated in both the VIP and MSP cohort, data and plasma from the MSP were used for this study. The present study was approved by the research ethics committee of Umeå University Hospital.

Case and control selection

In September 2005, subjects who had donated blood to the VIP or to the MSP were linked to the regional cancer register, covering more than $99 \%$ of breast cancer diagnoses. A total of 757 women were found to have been diagnosed with invasive breast cancer (ICD7 170) after baseline measurement and without any other cancer diagnosis (except non-melanoma skin). Of these women, the following were excluded: 108 cases from the screening cohort due to a time to diagnosis less than 6 months after baseline, 24 cases whose blood samples were restricted for use in another study, and 64 cases due to small remaining volume in stored samples. The current study thus included 561 breast cancer cases, of which 211 were from the VIP and 350 from the MSP. 
Information on tumour characteristics was extracted from medical records, pathology reports and the cancer registry, and cause of death was obtained from the National cause of death register. Oestrogen and progesterone receptor-positive tumours were defined as $\geq 0.1 \mathrm{fmol}$ receptor $/ \mu \mathrm{g}$ DNA.

For each case, one control without any cancer diagnosis (except non-melanoma skin cancer) at the date of diagnosis for the index case was randomly selected from the same subcohort. Case-control sets were matched for age at baseline ( \pm 6 months) and date at blood sampling ( \pm 2 months). In a few cases, the matching criteria were broadened for baseline age to \pm 9 months and for date at blood sampling to \pm 6 months.

\section{Biochemical analyses}

Plasma levels of leptin, adiponectin and C-peptide were measured at the Department of Medical Biosciences, Clinical Chemistry, Umeå University. Leptin and adiponectin levels were determined by radioimmunoassay with reagents from Linco Research (Missouri, USA) and Cpeptide concentrations were measured by radioimmunoassay, using reagents from Diagnostic Systems Laboratories (Webster, USA). Total coefficients of variation (CV) were for leptin $4.5 \%$ at $3.8 \mathrm{ng} / \mathrm{ml}$ and $5.5 \%$ at $23.6 \mathrm{ng} / \mathrm{ml}$; for adiponectin $5.9 \%$ at $19.0 \mu \mathrm{g} / \mathrm{ml}$ and $9.1 \%$ at $75.0 \mu \mathrm{g} / \mathrm{ml}$; and for C-peptide $7.3 \%$ at $0.5 \mathrm{ng} / \mathrm{ml}$ and $3.9 \%$ at $5.9 \mathrm{ng} / \mathrm{ml}$. HbA1c levels were measured at the Department of Clinical Chemistry, Karolinska University Hospital, Solna, Sweden. Analyses were performed on cryopreserved erythrocyte fraction measured by high performance liquid chromatography (Bio-Rad, Variant II); a method with total CVs of less than $5 \%$ within low and high HbA1c levels. HbA1c levels are expressed as monoS units (National Glycohemoglobin Standardization Program unit $\times 0.9718-$ $0.8925)$, as is used in clinical chemistry in Sweden. HbA1c levels were not measured in 32 case-control sets due to lack of erythrocytes in some samples. In all biochemical analyses, case-control sets were analysed in the same batch, and laboratory personnel were blinded to casecontrol status.

Intraclass correlations were previously calculated for two measurements of fasting levels of leptin and C-peptide in plasma and HbA1c in erythrocytes, from blood samples collected from 38 men with a 1-month interval [7]. Intraclass correlations were all higher than 0.90 .

\section{Statistical analyses}

Wilcoxon signed-rank tests were used to test for differences in measured values between cases and controls. Marginal homogeneity test was used to test for case-control differences in BMI-distribution over three categories, and McNemar test was used to test for differences in the binary categorisation of HRT user/non-user. To assess crosssectional interrelationships between exposure variables, we used Spearman's partial correlation coefficients, adjusted for case-control status, age and fasting time.

Conditional logistic regression was used to calculate odds ratios (OR) as estimates of relative risk for breast cancer, and $95 \%$ confidence intervals (CI). All risk estimates were also assessed with adjustments for BMI (continuous) and HRT use. Number of births and age at first delivery were examined as potential confounders (data available for $84 \%$ of women), however the inclusion of these variables in the regression models did not appreciably change the risk estimates and thus were not retained in the models. The results from our study did not appreciably change when we performed a sensitivity analysis that excluded 95 cases diagnosed less than two years after study entry.

We stratified the analysis of breast cancer incidence by age at diagnosis $(<55, \geq 55$ years; as a proxy for menopausal status at diagnosis), and by cases' tumour stage and ER/PR status at diagnosis. Results are not presented for the full study group because hormonal aetiological factors for breast cancer are known to differ among pre- and postmenopausal women [1]. Tumour stage is graded based on TNM status, and determines how far the tumour has progressed at diagnosis. We divided stage into the groups of stage I and stage II-IV. We also examined BMI as a possible effect modifier by performing unconditional regression analyses, adjusted for matching factors and HRT use, in groups of normal weight (BMI $<25 \mathrm{~kg} / \mathrm{m}^{2}$ ) and overweight-obese (BMI $\geq 25 \mathrm{~kg} / \mathrm{m}^{2}$ ) women.

Since nearly all variables in our study increased with age, age-specific cut-points were calculated within age categories $<45,45-<55$, and $\geq 55$ years and the same tertile cutpoints were used across subgroups. As C-peptide levels were significantly higher among non-fasting subjects, only case-control sets with the same fasting status $(<4 \mathrm{~h} ; \geq 4 \mathrm{~h}$ since last meal) were included in analyses of C-peptide. Risk with BMI was also assessed using the World Health Organisation (WHO) categorisation: normal weight (BMI $<25 \mathrm{~kg} / \mathrm{m}^{2}$ ), overweight (BMI $25-<30 \mathrm{~kg} / \mathrm{m}^{2}$ ) and obesity $\left(\mathrm{BMI} \geq 30 \mathrm{~kg} / \mathrm{m}^{2}\right)$.

Linear trends in ORs were assessed by likelihood ratio tests, assigning an increasing score of 1, 2 and 3 to each increasing tertile level. Formal tests of heterogeneity between the ORs across tertiles in subgroups were based on $\chi^{2}$ statistics. Statistical analyses were performed using SAS (version 9.1, SAS Institute, Cary, NC) and STATA (version 9.2, StataCorp LP, College Station, Texas), and statistical significance was inferred at two-sided $P<0.05$. 


\section{Results}

Baseline characteristics

Baseline characteristics of cases and matched controls are shown in Table 1. Cases were more likely to be using HRT at baseline compared to controls (24.0 vs. $11.3 \%$ ). The median BMI and the proportion of subjects who were overweight were not significantly different between cases and controls.

Table 2 describes the characteristics of the breast cancer cases. Cases had a median age of 52.5 years at recruitment (40.4 years and 57.0 years in the VIP and MSP subcohorts, respectively), and the median time to diagnosis was 4.4 years (4.8 years and 4.3 years in the VIP and MSP subcohorts, respectively). ER and PR status was known for $495(88.2 \%)$ women, of which the majority $(62.4 \%)$ were $\mathrm{ER}+/ \mathrm{PR}+$ status. Of the 561 cases, 263 (46.9\%) were diagnosed as having a stage I tumour, 290 (51.7\%) were classified as stage II-IV and $8(1.4 \%)$ as unknown. Of women with known receptor status, the proportion of stage

Table 1 Baseline characteristics of exposures among breast cancer cases and controls

\begin{tabular}{|c|c|c|c|}
\hline & Cases $(n=561)$ & Controls $(n=561)$ & $P^{\mathrm{a}}$ \\
\hline \multicolumn{4}{|c|}{ Median (25-75th percentile) } \\
\hline Leptin, ng/ml & $14.1(9.4-21.5)$ & $14.5(8.6-22.1)$ & 0.84 \\
\hline Adiponectin, $\mu \mathrm{g} / \mathrm{ml}$ & $6.9(4.5-10.1)$ & $6.6(4.3-10.8)$ & 0.68 \\
\hline C-peptide, $\mathrm{ng} / \mathrm{ml}$ & $3.0(1.8-4.9)$ & $2.9(2.0-4.9)$ & 0.81 \\
\hline $\mathrm{HbA} 1 \mathrm{c},{ }^{\mathrm{b}} \%$ & $4.5(4.3-4.6)$ & $4.5(4.3-4.7)$ & $0.02^{\mathrm{c}}$ \\
\hline BMI, $\mathrm{kg} / \mathrm{m}^{2}$ & $24.6(22.3-27.3)$ & $24.9(22.6-27.6)$ & 0.27 \\
\hline BMI categories ${ }^{\mathrm{e}}$ & Number (\%) & & \\
\hline$<25 \mathrm{~kg} / \mathrm{m}^{2}$ & $293(54.0)$ & $275(50.1)$ & $0.10^{\mathrm{d}}$ \\
\hline $25-<30 \mathrm{~kg} / \mathrm{m}^{2}$ & $196(36.1)$ & $201(36.6)$ & \\
\hline$\geq 30 \mathrm{~kg} / \mathrm{m}^{2}$ & $54(9.9)$ & $73(13.3)$ & \\
\hline \multicolumn{4}{|l|}{ Current HRT use ${ }^{\mathrm{e}}$} \\
\hline Yes & $134(24.0)$ & $63(11.3)$ & $<0.00$ \\
\hline
\end{tabular}

HbA1c, glycated haemoglobin; BMI, body mass index; HRT, hormone replacement therapy

${ }^{a}$ Wilcoxon signed-rank test

b Expressed as Swedish monoS units = National Glycohemoglobin Standardization Program unit $\times 0.9718-0.8925$

c The paired differences (case-control) were mainly small $(81 \%$ of the sets were in the interval -0.5 to 0.5 ). The significant result from Wilcoxon's signed-rank test was largely caused by an imbalance between the differences -0.3 ( 55 sets) and 0.3 ( 30 sets). We have no other explanation for this imbalance but chance. The corresponding $P$-value for paired $t$-test was 0.93

d BMI was missing for 18 cases and 12 controls. HRT was missing for two cases and one control

e Marginal homogeneity test

${ }^{\mathrm{f}} \mathrm{McNemar}$ test
II-IV tumours that were ER+ $(76 \%)$ or PR+ $(61 \%)$ was slightly lower than the proportion of stage I tumours that were ER+ $(84 \%)$ or PR+ $(71 \%)$. Furthermore, women with a stage II-IV tumour were slightly younger at baseline (median 51.5 vs. 53.5 years).

BMI was strongly positively correlated with leptin $(r=0.72)$, and moderately correlated with C-peptide and HbA1c (Table 3). Adiponectin was negatively correlated with BMI, leptin and C-peptide, and was weakly negatively correlated with $\mathrm{HbA} 1 \mathrm{c}$.

Stratification by age at diagnosis

There was no significant association between BMI, leptin, adiponectin, C-peptide and risk of breast cancer when stratified by age at diagnosis ( $<55$ or $\geq 55$ years; Table 4$)$. The associations with BMI remained non-significant when categorised according to the WHO criteria (data not shown). HbA1c analysed in tertiles was significantly inversely related to risk among women $\geq 55$ years of age at diagnosis (OR for highest vs. lowest tertile $=0.61,95 \% \mathrm{CI}$, $0.40-0.94, P_{\text {trend }}=0.02$ ) whereas no association was found among women $<55$ years at diagnosis, however the differences were not statistically significant $\left(P_{\text {heterogeneity }}=\right.$ $0.17)$. Results were similar when we stratified by $<50$, $50-60,>60$ years at diagnosis, or by menopausal status at baseline, with essentially no differences between the groups.

Stratification by tumour stage

The associations of BMI, leptin and HbAlc with breast cancer risk differed significantly between the stage I diagnosed tumours and stage II-IV tumours $\left(P_{\text {heterogeneity }}\right.$ all <0.05) (Table 5). High levels of these factors were significantly (or borderline significantly) inversely associated with stage I disease, whereas higher levels of BMI and leptin were non-significantly related to an increased risk of stage II-IV disease. Obese women (WHO definition) were observed to have a decreased risk of breast cancer in the stage I group, whereas obesity was not related to risk in the stage II-IV group; adjusted ORs for obesity vs. normal weight were 0.45 (95\% CI, 0.24-0.85) and 0.95 (95\% CI, $0.55-1.64)$, respectively. In the stage II-IV group, high levels of $\mathrm{HbA} 1 \mathrm{c}$ conferred an increased risk among overweight-obese women; OR for the highest vs. lowest tertile was $1.92\left(95 \% \mathrm{CI}, 1.00-3.68, P_{\text {trend }}=0.05\right)$, but not among women of normal weight; OR $0.62(95 \% \mathrm{CI}$, $\left.0.34-1.12, P_{\text {trend }}=0.13\right)\left(P_{\text {heterogeneity }}=0.02\right)$. BMI did not modify risk associations for any other risk factor than HbA1c.

There was no evidence that the associations differed significantly between the VIP and MSP cohorts. However, 
Table 2 Characteristics of breast cancer cases

\begin{tabular}{|c|c|c|}
\hline Characteristic & Number $(n=561)$ & $\%$ \\
\hline Age at recruitment, median years ${ }^{\mathrm{a}}$ & 52.5 & \\
\hline Time to diagnosis, median years ${ }^{\mathrm{b}}$ & 4.4 & \\
\hline \multicolumn{3}{|l|}{ ER/PR status ${ }^{c}$} \\
\hline $\mathrm{ER}+/ \mathrm{PR}+$ & 309 & 55.1 \\
\hline $\mathrm{ER}+/ \mathrm{PR}-$ & 85 & 15.1 \\
\hline $\mathrm{ER}-/ \mathrm{PR}+$ & 14 & 2.5 \\
\hline $\mathrm{ER}-/ \mathrm{PR}-$ & 87 & 15.5 \\
\hline Unknown & 66 & 11.8 \\
\hline \multicolumn{3}{|l|}{ Type of tumour } \\
\hline Ductal & 425 & 75.8 \\
\hline Lobular & 93 & 16.6 \\
\hline Medular & 12 & 2.1 \\
\hline Colloid & 6 & 1.1 \\
\hline Other & 17 & 3.0 \\
\hline Missing & 8 & 1.4 \\
\hline \multicolumn{3}{|l|}{ Stage } \\
\hline I & 263 & 46.9 \\
\hline IIA & 181 & 32.3 \\
\hline IIB & 74 & 13.2 \\
\hline IIIA & 12 & 2.1 \\
\hline IIIB & 9 & 1.6 \\
\hline IV & 14 & 2.5 \\
\hline Unknown & 8 & 1.4 \\
\hline \multicolumn{3}{|l|}{ Grade } \\
\hline Low & 105 & 18.7 \\
\hline Intermediate & 256 & 45.6 \\
\hline High & 172 & 30.7 \\
\hline Unknown & 28 & 5.0 \\
\hline \multicolumn{3}{|l|}{ Tumour size $(\mathrm{T})$} \\
\hline$\leq 2 \mathrm{~cm}(\mathrm{~T} 1)$ & 354 & 63.1 \\
\hline$>2$ and $\leq 5 \mathrm{~cm}(\mathrm{~T} 2)$ & 164 & 29.2 \\
\hline$\geq 5 \mathrm{~cm} \mathrm{(T3)}$ & 14 & 2.5 \\
\hline Unknown & 21 & 3.8 \\
\hline Missing & 8 & 1.4 \\
\hline \multicolumn{3}{|l|}{ Lymph node metastasis $(\mathrm{N})$} \\
\hline No (N0) & 319 & 56.9 \\
\hline 1-3 axillary lymph nodes (N1) & 173 & 30.8 \\
\hline 4-9 axillary lymph nodes (N2) & 1 & 0.2 \\
\hline Unknown & 60 & 10.7 \\
\hline Missing & 8 & 1.4 \\
\hline \multicolumn{3}{|l|}{ Distant metastasis $(\mathrm{M})$} \\
\hline No (M0) & 540 & 96.3 \\
\hline Yes (M1) & 13 & 2.3 \\
\hline Unknown & 8 & 1.4 \\
\hline
\end{tabular}

a 25 th to 75 th percentile $=49.7-60.0$. Median age at recruitment in the VIP $=40.4$ (40.0-50.1), MSP $=57.0$ (52.2-62.6)

b 25 th to 75 th percentile $=2.2-6.8$. Median time to diagnosis in the $\mathrm{VIP}=4.8$ (2.3-8.2), MSP $=4.3(2.2-6.4)$

c Receptor-positive tumours were defined as $\geq 0.1 \mathrm{fmol}$ receptor $/ \mu \mathrm{g}$ DNA
Table 3 Crossectional interrelationships ${ }^{\text {a }}$ between metabolic factors at baseline among cases and controls

\begin{tabular}{lrrll}
\hline & \multicolumn{1}{c}{ BMI } & Leptin & Adiponectin & C-peptide \\
\hline Leptin & 0.72 & & & \\
Adiponectin & -0.23 & -0.17 & & \\
C-peptide & 0.30 & 0.39 & -0.22 & \\
HbA1c & 0.24 & 0.20 & -0.13 & 0.21 \\
\hline
\end{tabular}

a Data presented as Spearman's partial correlation coefficients, adjusted for case-control status, age and fasting time. For all correlations, $P<0.01$

the BMI, leptin and $\mathrm{HbAlc}$ associations with risk according to tumour stage appeared somewhat stronger in the VIP cohort: for stage I tumours the OR for the highest vs. lowest tertile was $0.24\left(95 \% \mathrm{CI}, 0.15-0.75, P_{\text {trend }}=0.01\right)$ for BMI, $0.45\left(95 \%\right.$ CI $\left.0.22-0.91, P_{\text {trend }}=0.03\right)$ for leptin and $0.49\left(95 \% \mathrm{CI}, 0.19-1.24, P_{\text {trend }}=0.19\right)$ for HbA1c; for stage II-IV tumours the ORs were 1.89 (95\% CI, 0.99-3.59, $\left.P_{\text {trend }}=0.05\right), 1.91$ (95\% CI 1.00-3.66, $\left.P_{\text {trend }}=0.05\right)$ and $1.39\left(95 \%\right.$ CI $\left.0.65-2.96, P_{\text {trend }}=0.40\right)$, respectively.

\section{Stratification by ER/PR status}

There were only minor differences overall in the exposure-risk associations according to ER+, ER-, PR+, or PR- status, or different ER/PR status combinations, and none of these differences were statistically significant $\left(P_{\text {heterogeneity all }}>0.05\right)$ (data not shown).

\section{Discussion}

The main finding in this prospective study is that the associations of BMI, leptin and HbA1c with breast cancer risk differed significantly according to whether the tumour was diagnosed as stage I or stage II-IV. Elevated levels of these factors were inversely associated with stage I breast cancer, but were generally related to an increased risk of stage II-IV disease.

To our knowledge, no previous prospective study has reported breast cancer risk according to tumour stage at diagnosis for the exposures included in our study, except for BMI. Whilst the mechanisms underlying our observed strong decreased risks with stage I tumours are unclear, the suggestive positive association with stage II-IV tumours at diagnosis is supported by other epidemiological findings. Previous studies have reported that obesity in both pre- and post-menopausal women is associated with advanced disease at diagnosis, including large tumour size, high cellular proliferation and lymph node metastasis [4]. Increasing BMI is also significantly associated with higher 
Table 4 Odds ratios and 95\% confidence intervals for breast cancer risk according to tertiles ${ }^{\mathrm{a}}$ of BMI and insulin resistance related exposures, stratified by caseś age at diagnosis

\begin{tabular}{|c|c|c|c|c|c|c|}
\hline \multirow[t]{2}{*}{ Factor } & \multicolumn{3}{|c|}{$<55$ years $\left(n_{\text {cases }}=227\right)$} & \multicolumn{3}{|c|}{$\geq 55$ years $\left(n_{\text {cases }}=334\right)$} \\
\hline & Cases/controls & $\begin{array}{l}\text { Crude OR } \\
(95 \% \mathrm{CI})\end{array}$ & $\begin{array}{l}\text { Adjusted }{ }^{\mathrm{b}} \text { OR } \\
(95 \% \mathrm{CI})\end{array}$ & Cases/controls & $\begin{array}{l}\text { Crude OR } \\
(95 \% \mathrm{CI})\end{array}$ & $\begin{array}{l}\text { Adjusted }^{\mathrm{b}} \text { OR } \\
(95 \% \mathrm{CI})\end{array}$ \\
\hline \multicolumn{7}{|l|}{ BMI $\left(\mathrm{kg} / \mathrm{m}^{2}\right)$} \\
\hline $\mathrm{T} 1$ & $75 / 72$ & 1.00 & 1.00 & $115 / 97$ & 1.00 & 1.00 \\
\hline $\mathrm{T} 2$ & $71 / 71$ & $0.97(0.63-1.49)$ & $1.05(0.68-1.63)$ & $103 / 110$ & $0.80(0.55-1.17)$ & $0.81(0.55-1.21)$ \\
\hline $\mathrm{T} 3$ & $72 / 75$ & $0.93(0.60-1.43)$ & $0.90(0.58-1.40)$ & $97 / 108$ & $0.76(0.52-1.12)$ & $0.86(0.57-1.30)$ \\
\hline$P_{\text {trend }}$ & & 0.74 & 0.67 & & 0.16 & 0.45 \\
\hline$P_{\text {heterogeneity }}$ & & 0.49 & 0.83 & & & \\
\hline \multicolumn{7}{|l|}{ Leptin (ng/ml) } \\
\hline $\mathrm{T} 1$ & $78 / 76$ & 1.00 & 1.00 & $108 / 110$ & 1.00 & 1.00 \\
\hline $\mathrm{T} 2$ & $80 / 68$ & $1.15(0.74-1.78)$ & $1.08(0.69-1.68)$ & $119 / 110$ & $1.10(0.75-1.62)$ & $1.34(0.89-2.01)$ \\
\hline $\mathrm{T} 3$ & $69 / 83$ & $0.84(0.55-1.27)$ & $0.80(0.52-1.22)$ & $107 / 114$ & $0.96(0.65-1.40)$ & $1.15(0.76-1.74)$ \\
\hline$P_{\text {trend }}$ & & 0.40 & 0.29 & & 0.81 & 0.53 \\
\hline$P_{\text {heterogeneity }}$ & & 0.61 & 0.22 & & & \\
\hline \multicolumn{7}{|c|}{ Adiponectin (ug/ml) } \\
\hline $\mathrm{T} 1$ & $77 / 71$ & 1.00 & 1.00 & $105 / 116$ & 1.00 & 1.00 \\
\hline $\mathrm{T} 2$ & $78 / 66$ & $0.96(0.57-1.61)$ & $0.93(0.53-1.64)$ & $123 / 110$ & $1.25(0.85-1.83)$ & $1.21(0.80-1.83)$ \\
\hline $\mathrm{T} 3$ & $72 / 90$ & $0.57(0.31-1.06)$ & $0.56(0.28-1.11)$ & $106 / 108$ & $1.09(0.67-1.78)$ & $0.96(0.55-1.65)$ \\
\hline$P_{\text {trend }}$ & & 0.07 & 0.08 & & 0.58 & 0.95 \\
\hline$P_{\text {heterogeneity }}$ & & 0.08 & 0.16 & & & \\
\hline \multicolumn{7}{|c|}{ C-peptide $(\mathrm{ng} / \mathrm{ml})^{\mathrm{c}}$} \\
\hline $\mathrm{T} 1$ & $73 / 71$ & 1.00 & 1.00 & $87 / 104$ & 1.00 & 1.00 \\
\hline $\mathrm{T} 2$ & $75 / 61$ & $1.17(0.74-1.87)$ & $1.17(0.72-1.89)$ & $110 / 100$ & $1.28(0.88-1.85)$ & $1.26(0.85-1.88)$ \\
\hline $\mathrm{T} 3$ & $64 / 80$ & $0.76(0.47-1.23)$ & $0.75(0.44-1.29)$ & $105 / 98$ & $1.27(0.85-1.90)$ & $1.32(0.84-2.05)$ \\
\hline$P_{\text {trend }}$ & & 0.27 & 0.34 & & 0.22 & 0.20 \\
\hline$P_{\text {heterogeneity }}$ & & 0.09 & 0.13 & & & \\
\hline \multicolumn{7}{|l|}{ HbA1c (\%) } \\
\hline $\mathrm{T} 1$ & $88 / 81$ & 1.00 & 1.00 & $107 / 81$ & 1.00 & 1.00 \\
\hline $\mathrm{T} 2$ & $53 / 64$ & $0.77(0.48-1.23)$ & $0.89(0.54-1.48)$ & $133 / 126$ & $0.81(0.55-1.19)$ & $0.85(0.56-1.29)$ \\
\hline $\mathrm{T} 3$ & $59 / 55$ & $0.98(0.60-1.60)$ & $0.98(0.58-1.64)$ & $89 / 122$ & $0.57(0.38-0.84)$ & $0.61(0.40-0.94)$ \\
\hline$P_{\text {trend }}$ & & 0.85 & 0.91 & & 0.004 & 0.02 \\
\hline$P_{\text {heterogeneity }}$ & & 0.09 & 0.17 & & & \\
\hline
\end{tabular}

OR, odds ratio; CI, confidence interval; BMI, body mass index; HbA1c, glycated haemoglobin

${ }^{a}$ Since nearly all variables in our study increased with age, tertile cut-points were calculated within baseline age categories $<45$, 45-<55, and $\geq 55$ years, and the same tertile cut-points were used across subgroups. The cut-points for BMI were $<22.2,22.2-24.6,>24.6(<45$ years); $<23.3,23.3-26.0,>26.0$ ( $45-<55$ years); $<24.2,24.2-27.4,>27.4$ ( $\geq 55$ years); for leptin $<8.2,8.2-14.2,>14.2(<45$ years); $<11.0,11.0-19.0$, $>19.0$ (45-<55 years); $<12.6,12.6-21.6,>21.6$ ( $\geq 55$ years); for adiponectin $<6.0,6.0-9.7,>9.7(<45$ years); $<5.0,5.0-8.1,>8.1(45-$ $<55$ years); $<4.9,4.9-9.1,>9.1$ ( $\geq 55$ years); for HbA1c $<4.3,4.3-4.5,>4.5$ ( $<45$ years); $<4.5,4.5-4.7,>4.7$, ( $45-<55$ years and $\geq 55$ years). Cut points for C-peptide were further divided according to fasting time before measurement; $\geq 4 \mathrm{~h}:<1.5,1.5-2.0,>2.0(<45$ years); $<1.7,1.7-$ $2.4,>2.4$ (45-<55 years); $<2.1,2.1-3.2,>3.2$ ( $\geq 55$ years); and $<4$ h fasting: $<2.9,2.9-4.6,>4.6$ ( $<45$ years and $45-<55$ years); $<3.4,3.4-5.7$, $>5.7$ ( $\geq 55$ years)

b Adjusted for BMI and HRT use. Leptin was not adjusted for BMI due to the high correlation $(r=0.72)$ with BMI. The BMI association was adjusted for HRT use only

${ }^{c}$ Only case-control sets with the same fasting time before blood sampling were included in analyses of C-peptide

rates of death due to breast cancer, compared with normalweight individuals [8]. Additionally, type 2 diabetes, a consequence of several years with insulin resistance and subsequent $\beta$-cell failure, is associated with increased tumour stage and size [9], independent of BMI. Thus, there is growing evidence that a metabolic profile comprising overweight and insulin resistance is related to tumour progression. The biological mechanisms underlying this 
Table 5 Odds ratios and 95\% confidence intervals for stage I versus stage II-IV breast tumours at diagnosis, according to tertiles ${ }^{\mathrm{a}}$ of BMI and insulin-resistance related exposures

\begin{tabular}{|c|c|c|c|c|c|c|}
\hline \multirow[t]{2}{*}{ Factor } & \multicolumn{3}{|c|}{ Stage I $\left(n_{\text {cases }}=263\right)$} & \multicolumn{3}{|c|}{ Stage II-IV $\left(n_{\text {cases }}=290\right)$} \\
\hline & Cases/controls & $\begin{array}{l}\text { Crude ORs } \\
(95 \% \mathrm{CI})\end{array}$ & $\begin{array}{l}\text { Adjusted }^{\mathrm{b}} \text { ORs } \\
(95 \% \mathrm{CI})\end{array}$ & Cases/controls & $\begin{array}{l}\text { Crude ORs } \\
(95 \% \mathrm{CI})\end{array}$ & $\begin{array}{l}\text { Adjusted }{ }^{\mathrm{b}} \text { ORs } \\
(95 \% \mathrm{CI})\end{array}$ \\
\hline \multicolumn{7}{|l|}{ BMI $\left(\mathrm{kg} / \mathrm{m}^{2}\right)$} \\
\hline $\mathrm{T} 1$ & $102 / 74$ & 1.00 & 1.00 & $85 / 95$ & 1.00 & 1.00 \\
\hline $\mathrm{T} 2$ & $80 / 74$ & $0.81(0.53-1.22)$ & $0.94(0.60-1.46)$ & $94 / 103$ & $0.99(0.66-1.47)$ & $0.99(0.66-1.48)$ \\
\hline $\mathrm{T} 3$ & $66 / 100$ & $0.48(0.31-0.75)$ & $0.48(0.30-0.78)$ & $99 / 80$ & $1.38(0.92-2.08)$ & $1.44(0.95-2.18)$ \\
\hline$P_{\text {trend }}$ & & 0.001 & 0.004 & & 0.14 & 0.10 \\
\hline$P_{\text {heterogeneity }}$ & & 0.001 & 0.001 & & & \\
\hline \multicolumn{7}{|l|}{ Leptin (ng/ml) } \\
\hline $\mathrm{T} 1$ & $102 / 88$ & 1.00 & 1.00 & $81 / 98$ & 1.00 & 1.00 \\
\hline $\mathrm{T} 2$ & $93 / 75$ & $1.07(0.71-1.61)$ & $1.19(0.76-1.86)$ & $105 / 97$ & $1.32(0.88-2.00)$ & $1.32(0.87-2.01)$ \\
\hline $\mathrm{T} 3$ & $68 / 100$ & $0.61(0.40-0.92)$ & $0.64(0.41-1.00)$ & $104 / 95$ & $1.33(0.89-1.99)$ & $1.37(0.91-1.06)$ \\
\hline$P_{\text {trend }}$ & & 0.02 & 0.06 & & 0.18 & 0.14 \\
\hline$P_{\text {heterogeneity }}$ & & 0.01 & 0.01 & & & \\
\hline \multicolumn{7}{|c|}{ Adiponectin (ug/ml) } \\
\hline $\mathrm{T} 1$ & $78 / 88$ & 1.00 & 1.00 & $100 / 94$ & 1.00 & 1.00 \\
\hline $\mathrm{T} 2$ & $100 / 76$ & $1.49(0.95-2.33)$ & $1.44(0.86-2.41)$ & $98 / 99$ & $0.90(0.59-1.37)$ & $0.91(0.58-1.42)$ \\
\hline $\mathrm{T} 3$ & $85 / 99$ & $0.92(0.55-1.54)$ & $0.74(0.40-1.38)$ & $92 / 97$ & $0.80(0.45-1.41)$ & $0.83(0.46-1.51)$ \\
\hline$P_{\text {trend }}$ & & 0.80 & 0.42 & & 0.44 & 0.53 \\
\hline$P_{\text {heterogeneity }}$ & & 0.70 & 0.88 & & & \\
\hline \multicolumn{7}{|c|}{ C-peptide $(\mathrm{ng} / \mathrm{ml})^{\mathrm{c}}$} \\
\hline $\mathrm{T} 1$ & $73 / 74$ & 1.00 & 1.00 & $83 / 100$ & 1.00 & 1.00 \\
\hline $\mathrm{T} 2$ & $94 / 70$ & $1.34(0.86-2.07)$ & $1.21(0.75-1.96)$ & $90 / 88$ & $1.22(0.82-1.83)$ & $1.21(0.80-1.83)$ \\
\hline $\mathrm{T} 3$ & $72 / 95$ & $0.76(0.49-1.19)$ & $0.83(0.49-1.42)$ & $95 / 80$ & $1.50(0.96-2.34)$ & $1.39(0.87-2.23)$ \\
\hline$P_{\text {trend }}$ & & 0.22 & 0.54 & & 0.08 & 0.16 \\
\hline$P_{\text {heterogeneity }}$ & & 0.03 & 0.16 & & & \\
\hline \multicolumn{7}{|l|}{ HbA1c (\%) } \\
\hline $\mathrm{T} 1$ & $102 / 64$ & 1.00 & 1.00 & $91 / 97$ & 1.00 & 1.00 \\
\hline $\mathrm{T} 2$ & $89 / 98$ & $0.55(0.35-0.87)$ & $0.58(0.35-0.96)$ & $96 / 90$ & $1.14(0.76-1.71)$ & $1.18(0.77-1.81)$ \\
\hline $\mathrm{T} 3$ & $59 / 88$ & $0.42(0.27-0.67)$ & $0.47(0.28-0.80)$ & $85 / 85$ & $1.07(0.70-1.63)$ & $1.04(0.68-1.60)$ \\
\hline$P_{\text {trend }}$ & & $<0.001$ & 0.005 & & 0.75 & 0.87 \\
\hline$P_{\text {heterogeneity }}$ & & 0.003 & 0.03 & & & \\
\hline
\end{tabular}

OR, odds ratio; CI, confidence interval; BMI, body mass index; HbA1c, glycated haemoglobin

${ }^{a}$ Age-specific tertile cut-points of exposure factors were used, as described in Table 4, footnote (a)

b Adjusted for BMI and HRT use. Leptin was not adjusted for BMI due to the high correlation $(\mathrm{r}=0.72)$ with BMI. The BMI association was adjusted for HRT use only

c Only case-control sets with the same fasting time before blood sampling were included in analyses of C-peptide

relation are thought to involve (1) increased bioavailable oestrogen levels, (2) elevated insulin and insulin-like growth factor-1 (IGF-I) levels, and (3) the action of adipocyte-derived adipocytokines such as leptin (growthstimulating effects) and adiponectin (inhibitory effects) [10-13].

In our study, we observed a non-significant inverse association between C-peptide levels and (i) a younger age $(<55$ years $)$ at diagnosis and (ii) risk of stage I tumours. Conversely, a non-significant positive association was observed with an older age ( $\geq 55$ years) at diagnosis, and risk of stage IV tumours. Although most [14-18] (but not all [19]) case-control studies reported a positive relation between hyperinsulinaemia and breast cancer risk, most previous prospective studies showed no association with overall risk [20-25]. However, when stratified by age or menopausal status, two prospective studies [24, 25] observed a similar difference in risk estimates to what we observed in our study. The mechanisms for a possible inverse association of BMI and insulin with breast cancer 
diagnosis at a younger (premenopausal) age, or with early stage breast cancer, are unknown. Previous studies have demonstrated that high circulating IGF-I levels are associated with increased breast cancer risk in pre- but not postmenopausal women [26]. IGF-I has similar structural and functional features to insulin [27] and there is some evidence that IGF-I enhances insulin sensitivity and lowers blood glucose in insulin-resistant states [27, 28]. Possibly, an inverse association between C-peptide levels and breast cancer risk in some subgroups could be partly explained by these insulin-sensitising effects of IGF-I.

A previous pooled analysis of prospective cohort studies has shown that obesity is associated with an increased breast cancer risk among postmenopausal women, but with a slight decreased risk among premenopausal women [1]. In our study there were no clear associations of BMI with breast cancer risk according to age at diagnosis, although our confidence intervals do include the pooled risk estimate values. Previous studies indicate that the BMI-risk association might be stronger among women older than 65 years $[1,2]$, of which there were few women in our cohort. Our BMI risk estimates may also have been attenuated due to self-report height and weight measurements that were obtained for most women in the MSP cohort, which is likely to have led to underestimation of BMI values, particularly among overweight women [29]. Nevertheless, when we separately analysed women from the VIP cohort, who did have measured values of height and weight, our risk estimates according to age at diagnosis were similar to women with self-reported values. However, our results for BMI by tumour stage did appear slightly stronger in the VIP cohort.

Previous epidemiological studies of leptin and breast cancer risk have observed no association [30, 31], or a weak inverse association among premenopausal women [32]. In our study, no risk-difference was found between the groups based on age at diagnosis. Contrary to other epidemiological studies [33-36], and the reported insulinsensitising, anti-proliferative and apoptotic activity of adiponectin [10, 11, 13, 37], we did not observe a statistically significant inverse association between adiponectin levels and breast cancer risk in this study.

$\mathrm{HbA1c}$ reflects the average plasma glucose concentration over the preceding 6-8 weeks, and is considered a marker for impaired glucose metabolism [38]. Our findings for $\mathrm{HbA} 1 \mathrm{c}$ are consistent with the only other prospective cohort study [39] that we know of, that has examined the association of $\mathrm{HbAlc}$ with breast cancer risk. Lin et al. [39] showed an inverse association of HbAlc with breast cancer among postmenopausal women, and no association among premenopausal women, which was similar to our results stratified by age at diagnosis. Whilst Lin and colleagues did not examine the effects of $\mathrm{HbA} 1 \mathrm{c}$ by tumour stage, they did observe an inverse association with well differentiated (low-grade) tumours and no association with poorly differentiated tumours [39]. In our study, HbA1c levels were significantly inversely associated with risk of stage I breast tumours, but were unrelated to stage II-IV tumours except when further stratified by BMI categories, where we observed a two-fold higher association for overweight women. It is possible that overweight may potentiate the effects of $\mathrm{HbAlc}$ in the same way that leptin, oestrogen, insulin and other mitogenic factors can act synergistically to increase proliferation and progression of breast tumour cells $[10,39,40]$. Other prospective studies have used alternate measures of glucose metabolism including fasting or post-load glucose, but have shown inconsistent results with breast cancer risk [21, 22, 41, 42].

Although it has been suggested that the aetiology of breast cancer may depend on its ER and PR status [3, 43], we found no evidence for effect modification by ER/PR status in our study. MacInnis et al. [2] also reported no overall differences in the association of body size measures and breast cancer risk according to ER/PR status, however among women at least 15 years post-menopause, body size measures were positively associated with ER+ tumours and weakly negatively associated with ER- tumours.

This study has several strengths, including the prospective, population-based study design and almost $100 \%$ complete coverage of incident cancers from the cancer registry. Another strength of our study is that we examined several factors related to overweight and insulin resistance. We had a relatively large sample size, however larger samples will be required to conclusively elucidate the associations by stage and other tumour characteristics, and within smaller subgroups such as premenopausal women, and by HRT use.

Only one blood sample was taken, which may not represent an individual's long-term exposure levels, however, we previously observed high intraclass correlations $(r>0.90)$ for measurements of fasting C-peptide, leptin and $\mathrm{HbA1c}$ in blood samples collected 1 month apart [7], suggesting that a single measurement accurately reflects at least short-term average levels. One of the limitations of our study is the difficulty in exploring whether some of our results were driven by differences in age, cohort, fasting time or tumour stage, since in our study these factors were related, e.g. older participants were more likely to be recruited from the MSP, have non-fasting measures, and were slightly more likely to be diagnosed with a stage I tumour. Although we were able to match or adjust for these factors, we could not examine their individual effects simultaneously. We tried to minimise the possibility of detection bias (i.e. that women having regular mammography would be more likely to be diagnosed with an earlystage cancer) by excluding all cases from the screening 
cohort with a time to diagnosis less than 6-months after baseline, and our results did not appreciably change when we excluded cases diagnosed less than two years after baseline. Another limitation was the lack of information on menopausal status at the time of cancer diagnosis, thus we used age as a proxy measure.

In conclusion, we found that several markers of overweight and insulin resistance, including BMI, leptin and HbA1c, may influence breast tumour initiation and progression.

Acknowledgements We thank Åsa Ågren, project database manager at the Medical Biobank, Umeå University Hospital, Sweden, for co-ordinating data, Sara Nilsson and Sören Holmgren, database executing officers at the Medical Biobank, Umeå University Hospital, Sweden, for managing and completing the study file, and Karin Hjertkvist, laboratory assistant at the Department of Medical Biosciences, Clinical Chemistry, Umeå University, for analysing plasma hormone levels. This study was funded by the World Cancer Research Fund, International Grant 2002/30, the Swedish Cancer Society 040417, and by the Västerbotten County Council. Anne Cust was supported by a $\mathrm{PhD}$ scholarship from the University of Sydney and a Research Scholar Award from the Cancer Institute NSW, Australia.

\section{References}

1. van den Brandt PA, Spiegelman D, Yaun SS et al (2000) Pooled analysis of prospective cohort studies on height, weight, and breast cancer risk. Am J Epidemiol 152:514-527

2. MacInnis RJ, English DR, Gertig DM et al (2004) Body size and composition and risk of postmenopausal breast cancer. Cancer Epidemiol Biomarkers Prev 13:2117-2125

3. Rosenberg LU, Einarsdottir K, Friman EI et al (2006) Risk factors for hormone receptor-defined breast cancer in postmenopausal women. Cancer Epidemiol Biomarkers Prev 15:2482-2488

4. Carmichael AR (2006) Obesity as a risk factor for development and poor prognosis of breast cancer. BJOG 113:1160-1166

5. Alberti KG, Zimmet P, Shaw J (2006) Metabolic syndrome-a new world-wide definition. A Consensus Statement from the International Diabetes Federation. Diabet Med 23:469-480

6. Weinehall L, Hallgren CG, Westman G et al (1998) Reduction of selection bias in primary prevention of cardiovascular disease through involvement of primary health care. Scand J Prim Health Care 16:171-176

7. Stocks T, Lukanova A, Rinaldi S et al (2007) Insulin resistance is inversely related to prostate cancer: A prospective study in Northern Sweden. Int J Cancer 120:2678-2686

8. Calle EE, Rodriguez C, Walker-Thurmond K et al (2003) Overweight, obesity, and mortality from cancer in a prospectively studied cohort of U.S. adults. N Engl J Med 348:1625-1638

9. Wolf I, Sadetzki S, Gluck I et al (2006) Association between diabetes mellitus and adverse characteristics of breast cancer at presentation. Eur J Cancer 42:1077-1082

10. Lorincz AM, Sukumar S (2006) Molecular links between obesity and breast cancer. Endocr Relat Cancer 13:279-292

11. Rose DP, Komninou D, Stephenson GD (2004) Obesity, adipocytokines, and insulin resistance in breast cancer. Obes Rev 5:153-165

12. Rose DP, Gilhooly EM, Nixon DW (2002) Adverse effects of obesity on breast cancer prognosis, and the biological actions of leptin (review). Int J Oncol 21:1285-1292
13. Vona-Davis L, Rose DP (2007) Adipokines as endocrine, paracrine, and autocrine factors in breast cancer risk and progression. Endocr Relat Cancer 14:189-206

14. Bruning PF, Bonfrer JM, van Noord PA et al (1992) Insulin resistance and breast-cancer risk. Int J Cancer 52:511-516

15. Yang G, Lu G, Jin F et al (2001) Population-based, case-control study of blood C-peptide level and breast cancer risk. Cancer Epidemiol Biomarkers Prev 10:1207-1211

16. Del Giudice ME, Fantus IG, Ezzat S et al (1998) Insulin and related factors in premenopausal breast cancer risk. Breast Cancer Res Treat 47:111-120

17. Schairer C, Hill D, Sturgeon SR et al (2004) Serum concentrations of IGF-I, IGFBP-3 and c-peptide and risk of hyperplasia and cancer of the breast in postmenopausal women. Int J Cancer 108:773-779

18. Malin A, Dai Q, Yu H et al (2004) Evaluation of the synergistic effect of insulin resistance and insulin-like growth factors on the risk of breast carcinoma. Cancer 100:694-700

19. Jernstrom H, Barrett-Connor E (1999) Obesity, weight change, fasting insulin, proinsulin, C-peptide, and insulin-like growth factor-1 levels in women with and without breast cancer: the Rancho Bernardo Study. J Womens Health Gend Based Med $8: 1265-1272$

20. Kaaks R, Lundin E, Rinaldi S et al (2002) Prospective study of IGF-I, IGF-binding proteins, and breast cancer risk, in northern and southern Sweden. Cancer Causes Control 13:307-316

21. Muti P, Quattrin T, Grant BJ et al (2002) Fasting glucose is a risk factor for breast cancer: a prospective study. Cancer Epidemiol Biomarkers Prev 11:1361-1368

22. Mink PJ, Shahar E, Rosamond WD et al (2002) Serum insulin and glucose levels and breast cancer incidence: the atherosclerosis risk in communities study. Am J Epidemiol 156:349-352

23. Keinan-Boker L, Bueno De Mesquita HB, Kaaks R et al (2003) Circulating levels of insulin-like growth factor I, its binding proteins $-1,-2,-3$, C-peptide and risk of postmenopausal breast cancer. Int J Cancer 106:90-95

24. Toniolo P, Bruning PF, Akhmedkhanov A et al (2000) Serum insulin-like growth factor-I and breast cancer. Int $\mathrm{J}$ Cancer 88:828-832

25. Verheus M, Peeters PH, Rinaldi S et al (2006) Serum C-peptide levels and breast cancer risk: Results from the European prospective investigation into cancer and nutrition (EPIC). Int $\mathrm{J}$ Cancer 119:659-667

26. Renehan AG, Harvie M, Howell A (2006) Insulin-like growth factor (IGF)-I, IGF binding protein-3, and breast cancer risk: eight years on. Endocr Relat Cancer 13:273-278

27. Clemmons DR (2006) Involvement of insulin-like growth factor-I in the control of glucose homeostasis. Curr Opin Pharmacol 6:620-625

28. Frystyk J (2004) Free insulin-like growth factors - measurements and relationships to growth hormone secretion and glucose homeostasis. Growth Horm IGF Res 14:337-375

29. Gorber SC, Tremblay M, Moher D et al (2007) A comparison of direct vs. self-report measures for assessing height, weight and body mass index: a systematic review. Obes Rev 8:307-326

30. Stattin P, Soderberg S, Biessy C et al (2004) Plasma leptin and breast cancer risk: a prospective study in northern Sweden. Breast Cancer Res Treat 86:191-196

31. Mantzoros CS, Bolhke K, Moschos S et al (1999) Leptin in relation to carcinoma in situ of the breast: a study of pre-menopausal cases and controls. Int J Cancer 80:523-526

32. Petridou E, Papadiamantis Y, Markopoulos C et al (2000) Leptin and insulin growth factor I in relation to breast cancer (Greece). Cancer Causes Control 11:383-388

33. Tworoger SS, Eliassen AH, Kelesidis T et al (2007) Plasma adiponectin concentrations and risk of incident breast cancer. J Clin Endocrinol Metab 92:1510-1516 
34. Miyoshi Y, Funahashi T, Kihara S et al (2003) Association of serum adiponectin levels with breast cancer risk. Clin Cancer Res 9:5699-5704

35. Mantzoros C, Petridou E, Dessypris N et al (2004) Adiponectin and breast cancer risk. J Clin Endocrinol Metab 89:1102-1107

36. Chen DC, Chung YF, Yeh YT et al (2006) Serum adiponectin and leptin levels in Taiwanese breast cancer patients. Cancer Lett 237:109-114

37. Dieudonne MN, Bussiere M, Dos Santos E et al (2006) Adiponectin mediates antiproliferative and apoptotic responses in human MCF7 breast cancer cells. Biochem Biophys Res Commun 345:271-279

38. Peacock I (1984) Glycosylated haemoglobin: measurement and clinical use. J Clin Pathol 37:841-851

39. Lin J, Ridker PM, Rifai N et al (2006) A prospective study of hemoglobin A1c concentrations and risk of breast cancer in women. Cancer Res 66:2869-2875
40. Catalano S, Mauro L, Marsico S et al (2004) Leptin induces, via ERK1/ERK2 signal, functional activation of estrogen receptor alpha in MCF-7 cells. J Biol Chem 279:19908-19915

41. Manjer J, Kaaks R, Riboli E et al (2001) Risk of breast cancer in relation to anthropometry, blood pressure, blood lipids and glucose metabolism: a prospective study within the Malmo Preventive Project. Eur J Cancer Prev 10:33-42

42. Jee SH, Ohrr H, Sull JW et al (2005) Fasting serum glucose level and cancer risk in Korean men and women. JAMA 293:194-202

43. Althuis MD, Fergenbaum JH, Garcia-Closas M et al (2004) Etiology of hormone receptor-defined breast cancer: a systematic review of the literature. Cancer Epidemiol Biomarkers Prev 13:1558-1568 